\title{
You May Call Me Professor: Professor Form of Address in Email Communication and College Student Reactions to Not Knowing What to Call Their Professors
}

\author{
Grace M. Hildenbrand (1) \\ Evan K. Perrault $(1)$ \\ Taylor M. Devine (1)
}

Keywords: form of address, instructional communication, email, instructor-student relationship, communication accommodation theory, professor

\begin{abstract}
This experimental study tested whether a professor's form of address (FOA) and email signature influenced students' perceptions of the professor's credibility, approachability, and likability. Guided by communication accommodation theory, the study investigated the likelihood that students would reciprocate a professor's FOA in email communication. Participants were randomly assigned to one of seven conditions varying by professor FOA (doctor, professor, first name) and email signature (present or not), with a signature only control condition. Results indicated students were more likely to reciprocate the FOA when an email signature was not present. Open-ended responses suggested students perceive instructors more positively when instructors specify a FOA and feel anxious and uncertain when professors do not specify a FOA.
\end{abstract}

Professors often spend many years obtaining post-baccalaureate degrees, and some may have strong feelings about how they are addressed. These instructors might consider ways to get students to refer to them by a preferred name or title (e.g., doctor). For instance, an academic with a doctoral degree gained media attention because she corrected a flight attendant for calling her "Miss" as opposed to "Doctor" (Eustachewich, 2018). Another story went viral when a student accidentally submitted an assignment 
referring to the instructor as "professor whats his nuts" (Bruner, 2018). Instances such as these showcase how an instructor's form of address (FOA) can have implications that attract attention depending on its use and interpretation. Because forms of address are essential for determining the expected roles of each interactant (Morand, 1996), instructors often make their preferred forms of address clear at the start of each semester. When instructors do not, students may resort to other cues to determine what to call their professors.

In United States of America universities, professors are typically addressed by title and students by first name to maintain a professional relationship (Formentelli \& Hajek, 2016). Students typically refer to their professors by title last name (TLN), using titles such as "Doctor" or "Professor." However, some students may address their professors by first name (FN), or avoid addressing them (Curzan, 2014). For instance, while some students call their instructors by their first names, others are uncomfortable doing so (Formentelli \& Hajek, 2016). When addressing professors via email, however, students sometimes forego common etiquette, such as using formal titles (Thomas-Tate et al., 2017). The way professors are addressed can have implications for students' perceptions of professors' credibility, likability, and status (Sebastian \& Bristow, 2008; Takiff et al., 2001). One way professors can alert students to the form of address they prefer is through the way they sign their emails.

The current research investigates the relationship between how a professor signs emails and how students reply. More specifically, this study examines possible relationships between professor FOA in email and student perceptions of their credibility, approachability, and likability. Thus, this research may suggest best practices for professor FOA as they may influence the student-teacher relationship and create a positive classroom atmosphere.

\section{Forms of Address}

Forms of address consist of the way people name one another, and generally vary based on the setting, status of speaker, and status of person being addressed (Morand, 1996). FOA play a key role in determining the trajectory of future interactions (Morand, 1996). Within a relationship, exchange of a FOA can be reciprocal, in which both people address one another using the same FOA, or they can be nonreciprocal, in which a different FOA is used for each person (Brown \& Ford, 1961).

\section{Communication Accommodation Theory}

Communication accommodation theory (CAT) seeks to articulate ways people adapt to one another by communicating in manners that are similar to or different from another person (Giles, 1973). One reason for adapting communication is to facilitate the level of social distance between the interactants (Gasiorek \& Giles, 2015). When people communicate in ways that are similar to the other person (i.e., convergence) social distance is lessened, while communicating in ways that are different from receivers (i.e., divergence) increases social distance (Gasiorek \& Giles, 2015). Reciprocal forms of address tend to decrease social distance, while non-reciprocal forms tend to increase it (Morand, 1996).

The ways professors sign emails can provide cues for convergence or divergence and student perceptions of professors. For instance, an instructor insisting students use TLN to address them could be engaging in divergence, while an instructor insisting students use FN to address the instructor could be engaging in convergence. Use of TLN can indicate avoidance and superiority, while use of FN indicates warmth 
and familiarity with the other person (Morand, 1996). Similarly, with CAT, perceptions of convergence may result in speakers coming across as more attractive and friendly (Gallois et al., 2005). Thus, by selecting a title, professors may generate particular impressions of themselves among their students.

An email signature is a block of information with one's name and title, the name of the organization where they work, and contact information (Rains \& Young, 2006). Yet, students may not pick up on these particular cues sent via email. For instance, large numbers of students send informal emails to their professors tending not to include their formal titles (Worthen, 2017). When professors receive informal emails from students, they tend to have decreased liking for them, perceive them as less credible, and are less likely to follow through with the students' requests (Stephens et al., 2009). Further, instructors may be upset when students do not address them properly, which could result in a deteriorated instructorstudent relationship, and contribute to a negative classroom atmosphere. However, based on previous literature, it is unclear whether students notice these cues within email signatures, and whether they will utilize these cues to reciprocate a professor's FOA in their email reply.

RQ1: To what degree do participants reciprocate the professor's FOA in a response email?

\section{Student Perceptions Based on Professor Form of Address}

Student perceptions of an instructor's credibility, approachability, or likability may be influenced by FOA. Instructor credibility is comprised of the student's perception of their competence, trustworthiness, and goodwill (McCroskey \& Teven, 1999). All three dimensions of credibility positively influence student learning (Finn et al., 2009). College students perceive professors addressed by TLN to be more powerful (Stewart et al., 2003) and have more status (Takiff et al., 2001). Therefore, while students may perceive professors to be more credible if they use "Doctor" or "Professor," they may also perceive informal titles as generating more goodwill (i.e., instructor and student on an equal level).

Approachability includes being warm, kind, and having a good sense of humor (Perrine, 1998), and is another significant characteristic desired by college students (Niederriter et al., 2017). Students might differ in their perceptions of professor approachability based on the term of address such that professors who go by FN might seem more approachable than those who go by TLN. Likability is another useful instructor quality for promoting a positive classroom environment. Yet, by selecting a title, a professor potentially sacrifices perceptions of likability for power (Ellis \& Travis, 2007). Instructors that generate positive perceptions among their students may engender respect and increase chances that students will take future classes with them.

RQ2: What relationships exist among professor FOA and student perceptions of credibility, approachability, or likability?

\section{Clarifying Professor Forms of Address and Student Reactions}

Best practices suggest professors clarify how they would like to be addressed and list preferred FOA in their syllabi (Ellis \& Travis, 2007). College students prefer course syllabi labeled with titles of "Doctor" or "Professor" over syllabi labeled with a generic FOA such as Mr. or Ms., or those with no FOA (Wright, 2013). When students are unsure about how to address their instructor, they may default to using a 
formal title or refrain from addressing the instructor (Curzan, 2014). Because no formal standard exists for communicating preferred FOA, research is warranted for exploring student preferences regarding how to be informed of a professor's chosen FOA.

RQ3: How do students prefer to be informed of a professor's chosen FOA?

RQ4: How do students feel when they do not know what to call their instructors?

\section{Impressions From Instructors Clarifying Forms of Address}

In addition to credibility, approachability, and likability, students may form other impressions based on whether instructors tell them how they prefer to be addressed. Students may or may not appreciate instructors who make it clear how they prefer to be addressed and this might influence students' perceptions of instructors.

RQ5: How do students perceive instructors who indicate their preferred FOA in communication encounters?

\section{Determining How to Refer to Instructors}

While students use a variety of titles to refer to their instructors (Curzan, 2014), the frequency with which students use each title is not widely understood. In the classroom, strategies students use to avoid a FOA when communicating with an instructor include using "you," a general statement such as "excuse me," or raising their hands (Formentelli, 2009). However, scant research has examined which course of action students use to determine what to call their instructors. Such research would be helpful so instructors can understand strategies students are using in order to make finding FOA information easier for students.

RQ6: How do students determine how to address their instructors?

\section{Methods}

An online experiment and survey approved by the university's institutional review board was conducted to answer our research questions.

\section{Stimulus}

Participants were given a prompt asking them to imagine being enrolled in a communication course with a new professor. Then they read a welcome email from the professor providing course information and reminders for the first day of class. The study was a 3 (form of address: FN, doctor, professor) $\times 2$ (presence/absence of signature block) experimental design, with a signature only control condition. The forms of address were chosen based on research indicating these professor forms of address are commonly used by students (Takiff et al. 2001; Thomas-Tate et al., 2017). Participants were randomly assigned to one of these seven conditions. The content of all the emails prior to the signatures was 
identical. The email signature block included the professor name with credentials: "Jordan Pederson, PhD," followed by the title "Professor" on the next line, the department and university on the third line, and the professor's email address on the last line. The name "Jordan Pederson" was selected in an attempt to use a gender-neutral and relatively common name, and the similarity of the name to the Canadian professor "Jordan Peterson" was unintentional.

After reading through the email, respondents were told to imagine they had a family emergency arise that would result in them missing the first day of class. Then they were asked to compose an email to the professor to let them know they would miss the first day of class. After composing their email, participants completed scales regarding their perceptions of the professor.

\section{Measurement}

\section{Credibility}

Credibility was measured using McCroskey and Teven's (1999) three dimension credibility measurement. The construct has three subscales: competence $(<=.94)$, goodwill $(<=.93)$, and trustworthiness $(<=.93)$. Each subscale contains six items of oppositely worded adjectives measured on a seven-point semantic differential scale. Sample competence subscale items include "unintelligent/intelligent" and "inexpert/ expert"; goodwill subscale include "unconcerned with me/concerned with me" and "doesn't care about me/cares about me"; and trustworthiness subscale: "dishonest/honest" and "unethical/ethical."

\section{Approachability}

Approachability was measured using Porter et al's (2007) approachability measure $(<=.96)$. The sevenpoint semantic differential scale consists of 20 pairs of negative and positive adjectives. Sample items include: "unfriendly/friendly," "uninviting/inviting," and "closed/open."

\section{Likability}

Likability of the professor was measured using a likability scale $(<=.96)$ adapted from Jayanti and Whipple (2008). This scale contains four items rating participant level of agreement on a seven-point scale ( 1 = strongly disagree, 7 = strongly agree) for the prompt: "this professor seems ...," with items of "likeable," "nice," "pleasant," and "interesting."

\section{Open-Ended Questions}

To answer research question 3, one question asked: "What could instructors do to help you better know how you should address them in communication?" To answer research question 4, another question asked: "How do you feel when you do not know what to call your instructors?" To answer the fifth research question, a third question asked: "What do you think of an instructor who tells you how he or she would like to be addressed in communication encounters?" Finally, to answer the last research question, participants were asked: "How do you determine how to address your instructors (i.e., what to call them in your communication)?" 


\section{Open-Ended Data Analysis}

A coding scheme was developed to analyze the open-ended responses using a thematic analysis approach (Braun \& Clarke, 2006). The first author identified emergent themes and developed separate coding schemes for each question. Then the first author trained the third author in how to use the coding scheme. For each question, the first 300 responses were independently coded as an initial round of training (38\% of the data). After each round, the researchers resolved disagreements until $100 \%$ agreement was obtained for the responses. Upon achieving adequate percent agreement for each question after the first round, the rest of the responses were independently coded. Coding agreement was satisfactory for all themes with both rounds of coding (84 to $100 \%$ ).

\section{Participants}

Participants were students from a large Midwestern university who were recruited through a participation pool in the fall 2018 semester and offered extra credit for participation. The survey was taken by 836 participants; responses with over half missing data were deleted $(\mathrm{n}=17)$, and participant responses were removed for not meeting the age requirement $(n=1)$ or not being an undergraduate $(n=3)$, leaving a total of 815 responses for analysis.

A slight majority of participants identified as women $(n=456,56.2 \%)$. Participant ages ranged from 18-47 $(M=19.69, S D=1.92)$, and included 220 first-year students, 213 sophomores, 205 juniors, and 173 seniors. About two thirds $(n=542,66.8 \%)$ identified as Caucasian, $168(20.7 \%)$ as Asian, $39(4.8 \%)$ as Hispanic, 27 (3.3\%) as African American, 4 (.5\%) as Native American, 17 (2.1\%) as other, and 14 (1.7\%) did not respond. Almost three quarters of the participants $(72.17 \% ; n=586)$ indicated via a yes/ no question that they thought they had called an instructor by the wrong name at some point in college.

\section{Results}

\section{RQ1}

RQ1 asked if participants would reciprocate the professor's FOA in an email response. To analyze the research question, frequencies and percentages were calculated to determine whether the FOA was reciprocated (see Table 1). The student email responses to the professor were scored first by determining whether or not the participant reciprocated the FOA. For instance, in the "Doctor" condition, addressing "Doctor Pederson" would be considered reciprocation, while addressing "Jordan" would be considered non-reciprocation. If a participant did not reciprocate, the response was coded for the other FOA category it exemplified (Doctor, Professor, FN, Mr./Ms., none, or other). In the "Doctor" conditions, 67.23\% of students reciprocated, in the "Professor" conditions, $82.53 \%$ reciprocated, and in the FN conditions, $14.22 \%$ reciprocated the professor's FOA. 


\begin{tabular}{|c|c|c|c|c|c|c|c|c|c|}
\hline \multicolumn{10}{|c|}{$\begin{array}{l}\text { TABLE } 1 \\
\text { Frequencies/Percentages of Participant Email Responses to Sample Professor Email }\end{array}$} \\
\hline Condition & $\begin{array}{l}\text { Email } \\
\text { Signature }\end{array}$ & Reciprocated & $\begin{array}{l}\text { Did Not } \\
\text { Reciprocate }\end{array}$ & Doctor & Professor & $\begin{array}{l}\text { First } \\
\text { Name }\end{array}$ & Mr./Mrs. & None & Other \\
\hline $\begin{array}{l}\text { Doctor }+ \\
\text { Sig }\end{array}$ & Yes & $\begin{array}{l}75 \\
(64.55 \%)\end{array}$ & $\begin{array}{l}41 \\
(35.34 \%)\end{array}$ & -- & $\begin{array}{l}28 \\
(68.29 \%)\end{array}$ & $\begin{array}{l}1 \\
(2.44 \%)\end{array}$ & $\begin{array}{l}7 \\
(17.07 \%)\end{array}$ & $\begin{array}{l}3 \\
(7.32 \%)\end{array}$ & $\begin{array}{l}2 \\
(4.88 \%)\end{array}$ \\
\hline $\begin{array}{l}\text { Doctor } \\
\text { Only }\end{array}$ & No & $\begin{array}{l}83 \\
(70.34 \%)\end{array}$ & $\begin{array}{l}35 \\
(29.66 \%)\end{array}$ & -- & $\begin{array}{l}27 \\
(77.14 \%)\end{array}$ & 0 & $\begin{array}{l}5 \\
(14.29 \%)\end{array}$ & $\begin{array}{l}3 \\
(8.57 \%)\end{array}$ & 0 \\
\hline $\begin{array}{l}\text { Professor } \\
+ \text { Sig }\end{array}$ & Yes & \begin{tabular}{|l}
83 \\
$(73.45 \%)$
\end{tabular} & \begin{tabular}{|l}
30 \\
$(26.55 \%)$
\end{tabular} & $\begin{array}{l}19 \\
(63.33 \%)\end{array}$ & -- & 0 & $\begin{array}{l}5 \\
(16.67 \%)\end{array}$ & $\begin{array}{l}5 \\
(16.67 \%)\end{array}$ & $\begin{array}{l}1 \\
\text { (3.33\%) }\end{array}$ \\
\hline $\begin{array}{l}\text { Professor } \\
\text { Only }\end{array}$ & No & \begin{tabular}{|l}
106 \\
$(91.38 \%)$
\end{tabular} & $\begin{array}{l}10 \\
(8.62 \%)\end{array}$ & $\begin{array}{l}1 \\
(10.00 \%)\end{array}$ & -- & 0 & $\begin{array}{l}2 \\
(20.00 \%)\end{array}$ & $\begin{array}{l}4 \\
(40.00 \%)\end{array}$ & $\begin{array}{l}3 \\
(30.00 \%)\end{array}$ \\
\hline $\mathrm{FN}+\mathrm{Sig}$ & Yes & $\begin{array}{l}9 \\
(7.69 \%)\end{array}$ & $\begin{array}{l}108 \\
(92.31 \%)\end{array}$ & \begin{tabular}{|l}
36 \\
$(33.33 \%)$
\end{tabular} & \begin{tabular}{|l}
58 \\
$(53.70 \%)$
\end{tabular} & -- & $\begin{array}{l}8 \\
(7.41 \%)\end{array}$ & $\begin{array}{l}6 \\
(5.56 \%)\end{array}$ & 0 \\
\hline FN Only & No & \begin{tabular}{|l}
24 \\
$(20.69 \%)$
\end{tabular} & \begin{tabular}{|l}
92 \\
$(79.31 \%)$
\end{tabular} & $\begin{array}{l}2 \\
(2.17 \%)\end{array}$ & \begin{tabular}{|l}
76 \\
$(82.61 \%)$
\end{tabular} & -- & $\begin{array}{l}10 \\
(10.87 \%)\end{array}$ & $\begin{array}{l}3 \\
(3.26 \%)\end{array}$ & $\begin{array}{l}1 \\
(1.09 \%)\end{array}$ \\
\hline Sig Only & Yes & -- & -- & $\begin{array}{l}31 \\
(26.72 \%)\end{array}$ & \begin{tabular}{|l}
72 \\
$(62.07 \%)$
\end{tabular} & $\begin{array}{l}3 \\
(2.59 \%)\end{array}$ & $\begin{array}{l}6 \\
(5.17 \%)\end{array}$ & $\begin{array}{l}3 \\
(2.59 \%)\end{array}$ & $\begin{array}{l}1 \\
(.86 \%)\end{array}$ \\
\hline
\end{tabular}

Note. For form of address the percent is the frequency divided by the "Did not reciprocate" total.

To investigate what effect including a signature or not has on students' likelihood to reciprocate in their responses, a chi-square analysis was conducted. The chi-square indicated a significant result: $\left.\right|^{2}(1)=11.13$, $p=.001$, Cramer's $V=.13$, such that participants were more likely to reciprocate when no signature was present $(56.1 \%)$ than when a signature was present (43.9\%). In the "Doctor" conditions, 64.55\% in the signature condition and $70.34 \%$ in the no signature condition reciprocated the FOA. In the "Professor" conditions, $73.45 \%$ in the signature condition reciprocated while $91.38 \%$ in the no signature condition reciprocated. In the FN conditions, only $7.69 \%$ in the signature condition and $20.69 \%$ in the no signature condition addressed the professor by FN.

\section{RQ2}

To answer RQ2, asking whether a professor's FOA in the email affects students' perceptions of the professor, a 3 (doctor, professor, FN) $\times 2$ (email signature or not) MANOVA was conducted. The overall MANOVA was not statistically significant for FOA condition: Wilks' $\lambda=.99, F(10,1370)=.39, p=.95$, for email signature: Wilks' $\lambda=.99, F(5,685)=.99, p=.42$, or for the interaction between FOA condition and email signature: Wilks' $\lambda=.98, F(10,1370)=1.11, p=.35$.

Because the presence of a signature significantly impacted how a student replied, a one-way MANOVA was also conducted to determine if the presence of a signature might impact students' perceptions of the professor. The overall MANOVA was not statistically significant: Wilks' $\lambda=.99, F(5,806)=1.78, p=.12$ (see Table 2). 


\begin{tabular}{|c|c|c|c|c|c|c|c|}
\hline \multicolumn{8}{|c|}{$\begin{array}{l}\text { TABLE } 2 \\
\text { Means and Standard Deviations for } 3 \times 2 \text { MANOVA on Perceptions of Professor }\end{array}$} \\
\hline & \multicolumn{6}{|c|}{ Mean (SD) } & \multirow[b]{2}{*}{$\begin{array}{l}\text { One-Way ANOVAs } \\
\text { Including Control }\end{array}$} \\
\hline & \multicolumn{3}{|c|}{ Form of Address } & \multicolumn{3}{|c|}{ Email Signature } & \\
\hline & Doctor & Prof. & First Name & Sig. & No Sig. & Control & \\
\hline & $\mathrm{n}=\mathbf{2 3 5}$ & $n=229$ & $n=231$ & $n=345$ & $n=350$ & $n=117$ & \\
\hline Competence & $\begin{array}{l}5.71 \\
(.96)\end{array}$ & $\begin{array}{c}5.69 \\
(1.01)\end{array}$ & $5.73(.98)$ & $\begin{array}{l}5.78 \\
(.93)\end{array}$ & $\begin{array}{c}5.64 \\
(1.03)\end{array}$ & $\begin{array}{l}5.84 \\
(.89)\end{array}$ & $F(6,806)=1.20$, n.s. \\
\hline Trustworthiness & $\begin{array}{l}5.61 \\
(.93)\end{array}$ & $\begin{array}{l}5.56 \\
(.95)\end{array}$ & $5.59(.95)$ & $\begin{array}{l}5.60 \\
(.97)\end{array}$ & $\begin{array}{l}5.57 \\
(.92)\end{array}$ & $\begin{array}{c}5.67 \\
(1.02)\end{array}$ & $F(6,806)=.52$, n.s. \\
\hline Goodwill & $\begin{array}{l}5.33 \\
(.95) \\
\end{array}$ & $\begin{array}{c}5.24 \\
(1.06) \\
\end{array}$ & $5.32(1.10)$ & $\begin{array}{c}5.33 \\
(1.04) \\
\end{array}$ & $\begin{array}{c}5.27 \\
(1.04)\end{array}$ & $\begin{array}{c}5.35 \\
(1.08)\end{array}$ & $F(6,806)=.43$, n.s. \\
\hline Approachability & $\begin{array}{l}5.60 \\
(.85)\end{array}$ & $\begin{array}{l}5.58 \\
(.86)\end{array}$ & $5.66(.92)$ & $\begin{array}{l}5.64 \\
(.88)\end{array}$ & $\begin{array}{l}5.58 \\
(.87)\end{array}$ & $\begin{array}{l}5.49 \\
(.91)\end{array}$ & $F(6,807)=.81$, n.s. \\
\hline Likability & $\begin{array}{l}5.67 \\
(.94)\end{array}$ & $\begin{array}{c}5.60 \\
(1.11)\end{array}$ & $5.72(1.08)$ & $\begin{array}{c}5.68 \\
(1.04)\end{array}$ & $\begin{array}{c}5.64 \\
(1.05)\end{array}$ & $\begin{array}{c}5.50 \\
(1.12)\end{array}$ & $F(6,806)=1.09$, n.s. \\
\hline
\end{tabular}

Note. In addition to the overall MANOVA (reported in paper) a series of one-way ANOVAs were also conducted in order to account for the control (no signature with no form of address) condition, as running a $3 \times 2$ ANOVA does not allow for including the control condition. These results are reported in the far right column and indicate that the control condition is not significantly different from the other conditions for any of the dependent variables.

\section{RQ3}

RQ3 sought to understand strategies participants suggest an instructor could use to inform students of their preferred FOA $(\mathrm{N}=792$; see Table 3$)$. Six themes arose from the data.

\section{Tell Students}

The most prevalent response among participants (69.82\%) was a suggestion that the instructor tells students their preferred FOA in class. Some indicated that their professors already utilize this strategy. Sample comments include: "Acknowledge their title in class," "Introduce themselves," or "They tell us in the first day of class."

\section{State in Syllabus}

Many participants also indicated that the instructor could list their preferred FOA in their syllabi (24.24\%). Example statements from this category are: "Put it in the syllabus," and "Write on the syllabus what they like to be called."

\section{Email}

Some respondents recommended that an instructor mention their preferred FOA in an email by explicitly stating it or listing it at the end of an email (18.94\%). Sample comments are: "An initial email for the class is nice. If they'd prefer to be called something they could include it there," and "Close their emails with their preferred names." 
Small percentages of students indicated that an instructor does not need to do anything to let the class know how they prefer to be addressed or is it not an issue they encounter. Some also suggested an instructor could write their name on the board or incorporate it into a PowerPoint slide. Others mentioned that an instructor could post their preferred FOA on the course learning management system page (see Table 3).

\begin{tabular}{|l|l|l|}
\hline \multicolumn{3}{|l|}{$\begin{array}{l}\text { TABLE } 3 \\
\text { What Instructors Could Do to Help Students Know How to Address Them (N= 792) }\end{array}$} \\
\hline Themes & $\mathbf{n}(\%)$ & Examples \\
\hline Tell students & $553(69.82)$ & $\begin{array}{l}\text { "Address it in first class" } \\
\text { "They could tell you how they like to be addressed" }\end{array}$ \\
\hline State in syllabus & $192(24.24)$ & $\begin{array}{l}\text { "Add it to their syllabus" } \\
\text { "Clarify in the syllabus" }\end{array}$ \\
\hline Email & $150(18.94)$ & $\begin{array}{l}\text { "Include something in an email" } \\
\text { "They could also sign their initial email exactly how they want } \\
\text { to be addressed" }\end{array}$ \\
\hline Nothing & $30(3.79)$ & $\begin{array}{l}\text { "Nothing this is really not an issue" } \\
\text { "They do it as it is" }\end{array}$ \\
\hline Write on board or put in slide & $21(2.65)$ & $\begin{array}{l}\text { "Be sure to write his/her name on the board" } \\
\text { "By including their title on lecture slides" }\end{array}$ \\
\hline $\begin{array}{l}\text { Learning Management System } \\
\text { (LMS) }\end{array}$ & $20(2.53)$ & $\begin{array}{l}\text { "Instructors could also write how they would like to be } \\
\text { addressed on [name of LMS] for the class" } \\
\text { "Putting it on [name of LMS] would make things very clear" }\end{array}$ \\
\hline Other & $51(6.44)$ & $\begin{array}{l}\text { "Ask others" } \\
\text { "Be clear" }\end{array}$ \\
\hline Irrelevant & $5(.63)$ & $\begin{array}{l}\text { "Fast response to email" } \\
\text { "Listen to me" }\end{array}$ \\
\hline
\end{tabular}

\section{RQ4}

RQ4 asked how participants feel when they do not know how to address their instructors. Ten themes were revealed $(\mathrm{N}=787$; see Table 4$)$.

\section{Uncomfortable}

About one in four participants (25.92\%) indicated that they feel uncomfortable or strange when they do not know how to address their instructors. For instance, "A little uncomfortable," and "I feel very awkward."

\section{Do Not Want to Offend}

Many respondents explained that they are concerned that they will come across as offensive, rude, or unprofessional (18.30\%). Sample comments are: "I wish not to disrespect them," and "Impolite." 


\begin{tabular}{|c|c|c|}
\hline \multicolumn{3}{|c|}{$\begin{array}{l}\text { TABLE } 4 \\
\text { How Students Feel When They Are Unsure What to Call Their Instructors ( } N=787 \text { ) }\end{array}$} \\
\hline Themes & n (\%) & Examples \\
\hline Uncomfortable & $204(25.92)$ & $\begin{array}{l}\text { "Awkward" } \\
\text { "I feel uncomfortable" } \\
\text { "Weird" }\end{array}$ \\
\hline Do Not Want to Offend & $144(18.30)$ & $\begin{array}{l}\text { "Afraid to accidentally insult and/or offend my instructors" } \\
\text { "I feel slightly disrespectful" }\end{array}$ \\
\hline Nervous & $124(15.76)$ & $\begin{array}{l}\text { "Anxious" } \\
\text { "Scared" } \\
\text { "Timid" }\end{array}$ \\
\hline Confused & $109(13.85)$ & $\begin{array}{l}\text { "A bit confused, and disoriented" } \\
\text { "I feel a bit lost" }\end{array}$ \\
\hline Neutral & $91(11.56)$ & $\begin{array}{l}\text { "Don't have this concern" } \\
\text { "I feel indifferent" } \\
\text { "I usually know what to call them" }\end{array}$ \\
\hline Hard to Communicate & 71 (9.02) & $\begin{array}{l}\text { "I feel like I can't approach them" } \\
\text { "Maybe a bit hesitant when I want to ask a question" }\end{array}$ \\
\hline Embarrassed/Guilty & 39 (4.96) & $\begin{array}{l}\text { "Disappointed in myself for not knowing" } \\
\text { "I feel bad when I don't know how to address them properly" }\end{array}$ \\
\hline Positive & $21(2.67)$ & $\begin{array}{l}\text { "Completely fine" } \\
\text { "I feel comfortable" }\end{array}$ \\
\hline Dumb & $18(2.29)$ & $\begin{array}{l}\text { "I feel dumb" } \\
\text { "I feel stupid" }\end{array}$ \\
\hline Upset & $12(1.52)$ & $\begin{array}{l}\text { "Annoyed" } \\
\text { "Mildly frustrated" }\end{array}$ \\
\hline Other & $23(2.92)$ & $\begin{array}{l}\text { "Conflicted" } \\
\text { "Set back" }\end{array}$ \\
\hline Irrelevant & $6(.76)$ & $\begin{array}{l}\text { "Sir or Madame" } \\
\text { "Yes" }\end{array}$ \\
\hline
\end{tabular}

Note. The largest percentage of participants did not directly answer the question, but instead listed a strategy that they use when they do not know what to call their instructors ( $N=235,29.86 \%)$. For instance, "I try to avoid saying their name."

\section{Nervous}

Several respondents indicated that they feel nervous when they do not know what to call their instructors (15.76\%). For instance: "Uneasy," "Very nervous," and "Worried."

\section{Confused}

Some participants suggested that they feel confused or uncertain about the situation (13.85\%). Example comments were: "I feel uncertain," "Unsure," and "Very confused."

\section{Neutral}

Other participants said that they did not feel positively or negatively, did not have an opinion on the matter, or suggested that this situation did not happen to them (11.56\%). For instance, "Does not happen," and "I don't feel anything in particular." 


\section{Hard to Communicate}

An indication that it was difficult to approach the instructor was also mentioned by certain participants (9.02\%). For example, "I am a bit skeptical when approaching them," and "Reluctant to talk."

\section{Embarrassed/Guilty}

For some participants, they feel embarrassed or guilty when they do not know how to address an instructor (4.96\%). For instance, "I feel embarrassed," and "I feel like I should have gotten to know them better."

Even fewer participants indicated that they feel positively, that they feel dumb or stupid, or that they feel frustrated about not knowing how to address their instructors (see Table 4).

\section{RQ5}

RQ5 asked how participants viewed instructors who clarify how they wish to be addressed $(\mathrm{N}=785$; see Table 5). Seven categories emerged.

\begin{tabular}{|c|c|c|}
\hline Themes & n (\%) & Examples \\
\hline $\begin{array}{l}\text { Nice/ } \\
\text { Approachable/ } \\
\text { Helpful }\end{array}$ & $168(21.40)$ & $\begin{array}{l}\text { "Considerate" } \\
\text { "Easier to talk to" } \\
\text { "Helpful" }\end{array}$ \\
\hline $\begin{array}{l}\text { Knowledgeable/ } \\
\text { Professional/ Organized }\end{array}$ & 133 (16.94) & $\begin{array}{l}\text { "I think they are respectable" } \\
\text { "I would think that they are very on top of it" }\end{array}$ \\
\hline Neutral & $84(10.70)$ & $\begin{array}{l}\text { "Fine" } \\
\text { "I think that this is what they want to be called" } \\
\text { "Usual" }\end{array}$ \\
\hline Generic Positive & $48(6.11)$ & $\begin{array}{l}\text { "Amazing" } \\
\text { "Great" } \\
\text { "I like them" }\end{array}$ \\
\hline Strict & 45 (5.73) & $\begin{array}{l}\text { "A bit bossy" } \\
\text { "At first, l'd feel as if this person is uptight" }\end{array}$ \\
\hline Depends & $42(5.35)$ & $\begin{array}{l}\text { "Big ego if they expect the exact title, relaxed and down to earth if } \\
\text { they prefer first name basis" } \\
\text { "Depending on the situation it may seem a bit pushy to me. If I ask } \\
\text { though, it's fine" }\end{array}$ \\
\hline Stuck Up & 29 (3.69) & $\begin{array}{l}\text { "He or she is a little pretentious if they insist on being called Dr." } \\
\text { "Self-righteous who demands to be referred to in a certain way" }\end{array}$ \\
\hline Other & 59 (7.52) & $\begin{array}{l}\text { "A little annoying" } \\
\text { "Being wrongly addressed often" }\end{array}$ \\
\hline Irrelevant & $9(1.15)$ & $\begin{array}{l}\text { "By calling them professor" } \\
\text { "I don't understand the question" }\end{array}$ \\
\hline
\end{tabular}

Note. The largest percentage of participants did not directly answer the question, but instead expressed that they like or appreciate that the instructor tells the students how to address them ( $\mathrm{N}=305,38.85 \%)$. For instance, "I like it." 


\section{Nice/Approachable/Helpful}

Participants felt that when instructors indicate how they desire to be addressed that the instructors seem nice, caring, or approachable (21.40\%). Example comments were: "I think they are welcoming and friendly," and "nice and easy going."

\section{Knowledgeable/Professional/Organized}

Some respondents perceived the instructors as competent, professional, honest, or prepared (16.94\%). For instance, "They are smart," "They usually seem to be more professional," and "Very organized and focused."

\section{Neutral}

Other participants indicated that they do not have an opinion or that they do not feel differently toward the professor (10.70\%). For example, "Don't feel different," "Makes sense," or "No opinion."

\section{Generic Positive}

Several respondents suggested that they feel positively toward the instructor but did not use a specific descriptor (6.11\%). Sample comments were: "Good," "I like those instructors," or "Wonderful."

\section{Strict}

Some participants indicated that an instructor comes across negatively, perceived as strict, bossy, or intimidating when they clarify what they want to be called (5.73\%). Example comments demonstrating this category were: "I think they are a little intimidating," and "I think they are a bit strict sometimes."

\section{Depends}

A small percentage of participants suggested that perceptions of the professor depend on how the professor says what they want to be called or which FOA they use (5.35\%). For example, "As long as they are not rude about how to address them it is fine with me," and "I think it can make the professor either more laid back or more strict.”

\section{Stuck Up}

The final category that emerged was for students perceiving an instructor coming across as bragging or wanting to seem smart when mentioning a preferred FOA (3.69\%). For instance, "I think of them as slightly snobbish," and "Usually think they're stuck up."

\section{RQ6}

RQ6 investigated how students determine what to call their instructors. Eleven themes emerged $(\mathrm{N}=$ 794; see Table 6). 


\section{Default to Formal Title}

The largest percent of participants indicated they automatically use a formal title when addressing instructors (34.63\%). Sample comments include: "A good default is 'Prof. Last name," and "I always start formal."

\section{Listen to Introduction}

Just over one quarter of respondents stated that they pay attention to the way their instructors introduce themselves to determine how to address them (25.82\%). Example comments are: "Based on what they specify," and "Wait until they explain."

\section{Look at Syllabus}

Many participants said they look at the syllabus for how to address their instructors (21.79\%). For instance, "Look at the syllabus," and "What their syllabus says."

\section{Email}

Some respondents relied on an instructor email element to determine what to call them, such as an instructor's email signature (15.87\%). Sample comments were: "Email sent that has their name," or "Email signature typically."

\section{Education/Credentials}

Some participants indicated that they rely on the education level, degree information, or position information to determine what to call instructors (15.11\%). For example, "Based on their position," and "By their education background."

\section{Look up Information}

Looking up information about the instructor, often internet information, was a strategy listed by certain participants (9.70\%). For instance, participants noted: "Google the instructors," and "Look up the name online."

\section{Ask/Observe Other Students}

Some respondents claimed that they ask or observe other students to determine what to call their instructors (9.19\%). Sample comments included: "Ask questions of classmates," and "What others have called them."

\section{Ask the Instructor}

Asking the instructor what they want to be called was preferred by some participants (8.56\%). For example, participants stated: "Ask the instructors themselves," and "The response I get when I ask them."

\section{Avoid Addressing Instructor}

Other participants choose to refrain from addressing the instructor (5.16\%). Example comments included: "I just don't call them anything," and "I stay away from names, I say, 'excuse me' instead." 
Fewer participants indicated that they rely on the personality of the instructor or their relationship with an instructor, or demographic information such as age of the instructor to determine how to refer to them (see Table 6).

\begin{tabular}{|c|c|c|}
\hline \multicolumn{3}{|c|}{$\begin{array}{l}\text { TABLE } 6 \\
\text { How Students Determine How to Address Their Instructors }(N=794)\end{array}$} \\
\hline Themes & n (\%) & Examples \\
\hline Default to Formal Title & 275 (34.63) & $\begin{array}{l}\text { "Always started with Dr. [Last Name] unless they are a TA" } \\
\text { "I just go with professor if I'm unsure" }\end{array}$ \\
\hline Listen to Introduction & $205(25.82)$ & $\begin{array}{l}\text { "By listening to them address themselves" } \\
\text { "How they introduce themselves" }\end{array}$ \\
\hline Look at Syllabus & $173(21.79)$ & $\begin{array}{l}\text { "Check the syllabus" } \\
\text { "I look back at the syllabus because most of the time they put } \\
\text { what they like to be called in there" }\end{array}$ \\
\hline Email & $126(15.87)$ & $\begin{array}{l}\text { "By how they end their emails" } \\
\text { "Email signature" }\end{array}$ \\
\hline Education/Credentials & $120(15.11)$ & $\begin{array}{l}\text { "Based on the level of degree they have received" } \\
\text { "I do it based on if they are a professional or whether they are } \\
\text { just a teacher/grad student" }\end{array}$ \\
\hline Look Up Information & 77 (9.70) & $\begin{array}{l}\text { "Google it" } \\
\text { "Look them up on [name of institution] website to see what } \\
\text { titles they have" }\end{array}$ \\
\hline Ask/Observe Other Students & 73 (9.19) & $\begin{array}{l}\text { "Find out from someone in the class" } \\
\text { "I always see how others call the instructors" }\end{array}$ \\
\hline Ask the Instructor & $68(8.56)$ & $\begin{array}{l}\text { "Ask in class" } \\
\text { "Ask them for confirmation of what they would prefer to be } \\
\text { called" }\end{array}$ \\
\hline Avoid Addressing Instructor & $41(5.16)$ & $\begin{array}{l}\text { "I do not say anything. I just start the conversation with my } \\
\text { concern" } \\
\text { "I just email them and say hi to start it" } \\
\text { "I raise my hand and wait for them to come to me" }\end{array}$ \\
\hline Personality / Relationship & $24(3.02)$ & $\begin{array}{l}\text { "By their personality on the first day/week of class" } \\
\text { "How well we know each other" }\end{array}$ \\
\hline Demographics & $16(2.02)$ & $\begin{array}{l}\text { "Gender" } \\
\text { "I do this based upon the age" }\end{array}$ \\
\hline Other & $44(5.54)$ & $\begin{array}{l}\text { "By their names" } \\
\text { "I take a shot and hope it's correct" }\end{array}$ \\
\hline Irrelevant & $1(.13)$ & "Not very often" \\
\hline
\end{tabular}

\section{Discussion}

Our findings indicate that students are more likely to reciprocate a professor's FOA when they are provided with only a name, as opposed to a name and email signature. Perhaps students are confused by professors' email signatures since they typically contain multiple forms of address (e.g., name, position/ title, and degree information). Professor use of formal titles (divergence) such as "Doctor" or "Professor" 
resulted in greater reciprocation by students than FN (convergence). We found that even when a professor signs an email with a formal title such as "Doctor," among students who do not reciprocate, they are still apt to use another formal title such as "Professor," indicating deference. Therefore, if a professor chooses to engage in convergence by using FN, they will have to do more than sign their emails with their FN to convince students to use the FOA. However, if a professor engages in divergence and signs their emails with TLN, students will likely use TLN in email communication with them.

This tendency to use TLN is somewhat surprising, as college students are known for writing casual emails to professors that do not include formal titles (Worthen, 2017). However, sometimes students default to use of formal titles (Curzan, 2014). CAT also notes that organizations have norms related to hierarchy and power that influence communication (Giles \& Ogay, 2007). We discovered that students tend to follow these institutional norms by engaging in divergence and utilizing TLN when addressing the professor in a response email. Perhaps only a small percentage of students use overly casual emails or perhaps these results reflect a culture specific to this individual university. Or maybe students responded this way because they had never interacted with the professor before and decided to default to a formal title. Consequently, if professors want to increase their likelihood of being addressed by their first names, they could not only sign their emails with their first names, but also consider avoiding using an email signature.

Students have several ideas for how an instructor can inform them of their preferred FOA such as telling them in class, listing it in the syllabus, or including it in an introductory email. These are all places where students will commonly encounter and expect to find the information, and previous research supports these strategies (Ellis \& Travis, 2007). When instructors tell students how they want to be addressed, most students seem to be appreciative. Open-ended responses indicate students perceive the professors as nice and approachable, but also more competent, professional, and organized. This makes sense, as students do not have to put effort into figuring out what to call their instructors. However, instructors should be careful about how they indicate their preferred names to students so it does not come across as harsh or arrogant. Some students might have experienced frustration with professors who insisted that they be called "Doctor" in the past. Yet, because such small percentages of students expressed that they have negative impressions of professors who indicate how they want to be addressed, most students likely prefer having instructors clarify how they want to be addressed.

When students do not know how to address their instructors, many feel awkward, nervous, and confused. The results indicating students experience anxiety and uncertainty when they do not know what to call their instructors are consistent with Anxiety Uncertainty Management Theory because of the way that managing anxiety and uncertainty influences the resulting communication (Gudykunst, 1995; Gudykunst \& Nidisha, 2001). For instance, some students find it difficult to approach the instructor when they are unsure how to address them. This is understandable because it is more difficult for students to communicate with a professor when they do not know what to call them. Plus, almost three quarters of participants believe that they have accidentally called an instructor by the wrong name, and this likely makes them feel uncomfortable. This could be a result of students not paying attention to instructors' preferred forms of address, or because of instructors not clarifying how they want to be addressed. In order to determine what to call their instructor, students take on the role of detectives by using information-seeking strategies such as listening to the instructor's introduction, looking at the syllabus or email, looking up credentials, or asking others. 
While findings from the current study have clear implications for the instructor-student relationship, they may also be applicable to other contexts that utilize different forms of address. For instance, health-care provider-patient communication is a similar situation in which providers can choose whether they want patients to use TLN or FN when addressing them. Other relevant contexts would be religious, in terms of how congregants refer to pastors, or even political, regarding how citizens address political leaders. In these situations, the person in the leadership position could work to make their preferred FOA clear by explicitly sharing it upon first meeting the other person or in an email. For example, doctors could introduce themselves using the preferred forms of address upon meeting new patients for the first time, and pastors could state their preferred forms of address in their first sermons to their congregations. Making these preferred forms of address clear from the start would allow for the interactants to feel positively toward the speakers and generate rapport.

\section{Limitations and Future Research}

Despite a high degree of internal validity in this study's experimental design, use of a hypothetical scenario likely reduces the level of ecological validity. Future research should seek to manipulate actual professor email signatures, possibly over a few semesters, or using different email signatures for different classes, to investigate students' perceptions and how they reply to the professor. Future research could also examine why students prefer the term "Professor" and seem to avoid using a first name-even when a professor signs an email with their first name. Another limitation is the fact that the authors accidentally selected a sample professor name that happened to be the name of a well-known professor; as a result, it is possible that participants may have pictured a male professor and/or Jordan Peterson when providing their responses. Additionally, these results may be specific to the students at one particular university, so a similar study could be conducted at multiple universities from different areas to see if the results are similar. Future studies could also qualitatively assess students' uncertainty levels with different types of professor address email scenarios.

\section{Conclusions and Implications}

Though previous research has used CAT in an instructional context (Mazer \& Hunt, 2008) or studied CAT in the context of forms of address (Ryan et al., 1995), the present study explicitly examined utilization of CAT to study instructor forms of address. We extended the theory by arguing that professor use of TLN may be a form of divergence while use of FN may be a form of convergence. This research is important because using a FOA determines what role each person takes on in an interaction and has implications regarding social distance (Morand, 1996). Additionally, students must be informed of how to address their instructors so that they can feel more comfortable approaching them and so instructors are addressed as they wish, as this may influence how instructors perceive and communicate with their students.

While students address their professors with a variety of names or titles, many prefer formal titles such as "Professor" and avoid informal address forms such as FN. If professors have strong preferences for how they want to be addressed in their email communication, the findings from this research suggest not including a signature containing conflicting credentials or titles.

Not knowing what to call their instructors is a significant concern among many college students, and most of them appreciate being informed of an instructor's preferred FOA. However, instructors should 
share their preferred names or titles in a respectful way. A professor should make their preferred FOA clear, and list it in multiple places. For instance, they could announce what they want students to call them on the first day of class, list it in their syllabi, and sign emails with the preferred FOA. Not only will students be grateful, but many will also have more positive perceptions of the instructor, with the instructor being perceived as simultaneously more approachable and professional.

\section{References}

Braun, V., \& Clarke, V. (2006). Using thematic analysis in psychology. Pragmatics, 3(2), 77-101. https:// doi.org/10.1191/1478088706qp063oa

Brown, R., \& Ford, M. (1961). Address in American English. Journal of Abnormal and Social Psychology, 62(2), 375-385. https://doi.org/10.1037/h0042862

Bruner, R. (2018, September 21). Student's essay snafu is really one for the books. TIME. https://web. archive.org/web/20200504210439/https://time.com/5403063/essay-mistake-professor/

Curzan, A. (2014, April 14). Just call me . . Chronicle of Higher Education, 60. https://web.archive.org/ web/20190402075452/https://www.chronicle.com/blogs/linguafranca/2014/04/14/just-call-me/

Ellis, V. S., \& Travis, J. E. (2007). Professional titles in higher education: Do they matter to students? College Student Journal, 41(4), 1168-1183.

Eustachewich, L. (2018, September 7). Passenger with PhD ripped for insisting airline call her 'doctor.' New York Post. https://web.archive.org/save/https://nypost.com/2018/09/07/passenger-with-phdripped-for-insisting-airline-call-her-doctor/

Finn, A. N., Schrodt, P., Witt, P. L., Elledge, N., Jernberg, K. A., \& Larson, L. M. (2009). A meta-analytical review of teacher credibility and its associations with teacher behaviors and student outcomes. Communication Education, 58(4), 516-537. https://doi.org/10.1080/03634520903131154

Formentelli, M. (2009). Address strategies in a British academic setting. Pragmatics, 19(2), 179-196. https://doi.org/10.1075/prag.19.2.02for

Formentelli, M., \& Hajek, J. (2016). Address practices in academic interactions in a pluricentric language: Australian English, American English, and British English. Pragmatics, 26(4), 631-652. https://doi. org/10.1075/prag.26.4.05for

Gallois, C., Ogay, T., \& Giles, H. (2005). Communication accommodation theory: A look back and a look ahead. In W. B. Gudykunst (Ed.), Theorizing about intercultural communication (pp. 121-148). Sage.

Gasiorek, J., \& Giles, H. (2015). The role of inferred motive in processing nonaccommodation: Evaluations of communication and speakers. Western Journal of Communication, 79(4), 456-471. https:// doi.org/10.1080/10570314.2015.1066030

Giles, H. (1973). Accent mobility: A model and some data. Anthropological Linguistics, 15(2), 87-105. https://www.jstor.org/stable/30029508

Giles, H., \& Ogay, T. (2007). Communication accommodation theory. In B. B. Whaley \& W. Samter (Eds.), Explaining communication: Contemporary theories and exemplars (pp. 293-310). Lawrence Erlbaum.

Gudykunst, W. B. (1995). Anxiety/uncertainty management (AUM) theory: Current status. In R. Wiseman (Ed.), Intercultural communication theory (pp. 8-58). Sage.

Gudykunst, W. B., \& Nishida, T. (2001). Anxiety, uncertainty, and perceived effectiveness of communication across relationships and cultures. International Journal of Intercultural Relations, 25(1), 55-71. https://doi.org/10.1016/S0147-1767(00)00042-0 
Jayanti, R. K., \& Whipple, T. W. (2008). Like me . . like me not: The role of physician likability on service evaluations. Journal of Marketing Theory and Practice, 16(1), 79-86. https://doi.org/10.2753/ MTP1069-6679160106

Mazer, J. P., \& Hunt, S. K. (2008). "Cool” communication in the classroom: A preliminary examination of student perceptions of instructor use of positive slang. Qualitative Research Reports in Communication, 9(1), 20-28. https://doi.org/10.1080/17459430802400316

McCroskey, J. C., \& Teven, J. J. (1999). Goodwill: A reexamination of the construct and its measurement. Communication Monographs, 66(1), 90-103. https://doi.org/10.1080/03637759909376464

Morand, D. A. (1996). What's in a name? An exploration of the social dynamics of forms of address in organizations. Management Communication Quarterly, 9(4), 422-451. https://doi. org/10.1177/0893318996009004003

Niederriter, J. E., Eyth, D., \& Thoman, J. (2017). Nursing students' perceptions on characteristics of an effective clinical instructor. SAGE Open Nursing, 3, 1-8. https://doi.org/10.1177/2377960816685571

Perrine, R. (1998). "Student" views of the characteristics of instructors' approachability. Psychology Reports, 82(2), 519-525. https://doi.org/10.2466/pr0.1998.82.2.519

Porter, H., Wrench, J. S., \& Hoskinson, C. (2007). The influence of supervisor temperament on subordinate job satisfaction and perceptions of supervisor sociocommunicative orientation and approachability. Communication Quarterly, 55(1), 129-153. https://doi.org/10.1080/01463370600998517

Rains, S. A., \& Young, A. M. (2006). A sign of the times: An analysis of organizational members' email signatures. Journal of Computer-Mediated Communication, 11(4), 1046-1061. https://doi.org/10.1111/ j.1083-6101.2006.00307.x

Ryan, E. B., Hummert, M. L., \& Boich, L. H. (1995). Communication predicaments of aging: Patronizing behavior toward older adults. Journal of Language and Social Psychology, 14(1-2), 144-166. https:// doi.org/10.1177/0261927X95141008

Sebastian, R. J., \& Bristow, D. (2008). Formal or informal? The impact of style and dress and forms of address on business students' perceptions of professors. Journal of Education for Business, 83(4), 196-202. https://doi.org/10.3200/JOEB.83.4.196-201

Stephens, K. K., Houser, M. L., \& Cowan, R. L. (2009). R u able to meat me: The impact of students' overly casual email messages to instructors. Communication Education, 58(3), 303-326. https://doi. org/10.1080/03634520802582598

Stewart, T. L., Berkvens, M., Engles, W. A. E. W., \& Pass, J. A. (2003). Status and likability: Can the "mindful" woman have it all? Journal of Applied Social Psychology, 33(10), 2040-2059. https://doi. org/10.1111/j.1559-1816.2003.tb01874.x

Takiff, H. A, Sanchez, D. T., \& Stewart, T. L. (2001). What's in a name? The status implications of students' terms of address for male and female professors. Psychology of Women Quarterly, 25(2), 134-144. https://doi.org/10.1111/1471-6402.00015

Thomas-Tate, S., Daugherty, T. K., \& Bartkoski, T. J. (2017). Experimental study of gender effects on language use in college students' email to faculty. College Student Journal, 51(2), 222-226.

Worthen, M. (2017, May 14). U can't talk to ur professor like this. New York Times. http://web.archive. org/web/20200111190357/https://www.nytimes.com/2017/05/13/opinion/sunday/u-cant-talk-to-urprofessor-like-this.html

Wright, S. K. (2013). Instructors' address forms influence course ratings. Names, 61(2), 92-100. https:// doi.org/10.1179/0027773813Z.00000000049 